https://www.amerabra.org; https://fspu.uitm.edu.my/cebs; https://www.emasemasresources.com/ $9^{\text {th }}$ Asian Conference on Environment-Behaviour Studies Perdana Kota Bharu, Kelantan, Malaysia, 28-29 Jul 2021

\title{
The Legal Implications of a Sale of Property by the Malaysian Developers under the Private Lease Scheme: In two minds?
}

\author{
Noraziah Abu Bakar ${ }^{1}$, Ruzita Azmi², Azlinor Sufian ${ }^{3}$, Hartini Saripan $^{4}$ \\ ${ }^{1}$ Faculty of Law, Universiti Teknologi MARA, Shah Alam, Malaysia \\ 2 Universiti Utara Malaysia Kuala Lumpur Campus, Malaysia \\ ${ }^{2}$ College of Law, Prince Sultan University Riyadh, Kingdom of Saudi Arabia \\ 2 Faculty of Law, Universiti Teknologi MARA, Shah Alam, Malaysia \\ noraziah@uitm.edu.my, zita@uum.edu.my, asufian@psu.edu.sa, hartinisaripan.uitm.edu.my \\ Tel of $1^{\text {st }}$ Author: 0167786792
}

\begin{abstract}
This paper aims to evaluate the legal implications on the purchasers of the private lease scheme (PLS) for a property purchased from the developers. The law requires the developers to apply for subdivided title and transfer it to the purchasers. However, instead of transferring property ownership, in PLS, the developer is only transferring a 99-year lease over the purchased property. Upon expiry of the lease, the property shall be reverted to the proprietor of the land. Consequently, the purchasers were misled to believe that in return for the full payment, they will be transferred with ownership of the property
\end{abstract}

Keywords: Private Lease Scheme; Developer; Certificate of a lease; Misrepresentation.

eISSN: 2398-42870 2021. The Authors. Published for AMER ABRA cE-Bs by e-International Publishing House, Ltd., UK. This is an open access article under the CC BYNC-ND license (http://creativecommons.org/licenses/by-nc-nd/4.0). Peer-review under responsibility of AMER (Association of Malaysian Environment-Behaviour Researchers), ABRA (Association of Behavioural Researchers on Asians/Africans/Arabians) and CE-Bs (Centre for Environment-Behaviour Studies), Faculty of Architecture, Planning \& Surveying, Universiti Teknologi MARA, Malaysia.

DOI: https://doi.org/10.21834/ebpj.v6i17.2867

\subsection{Introduction}

The Malaysian housing developers are bound by the Housing Development (Control and Licensing) Act 1966 (HDA) when selling housing accommodation to the purchasers. The mandatory sale agreement (SPA) is provided under the Housing Development (Control and Licensing) Regulations 1989 (Regulations 1989) known as Schedule G for a landed property under construction issued with title, Schedule $\mathrm{H}$ for high-rise building under construction, Schedule I and $\mathrm{J}$ for the completed building. The SPA prescribed under Regulations 1989 must be strictly complied with by the developers. In Sentul Raya Sdn Bhd v Hariram Jayaram \& Ors and Other Appeals [2008] 4 CLJ 618, it was decided that the SPA is prescribed and regulated by the Regulations 1989. The SPA incorporates the developers' duty to apply for a subdivided title and transfer it to the purchaser. A PLS Scheme was mooted in Johor to lease a freehold land to the purchasers for the price paid by the purchasers. Upon expiry of the 99-year lease, the property shall be reverted to the owner of the land. The developers varied the SPA by incorporating clauses where the developers shall transfer a lease over the unit instead of transferring ownership of the unit upon issuance of a title and the property be reverted to the owner upon expiry of the lease. The purchasers from the PLS in Johor were not satisfied and brought the matters to court to sue the developer, Tropika Istimewa Development Sdn. Bhd.

eISSN: 2398-4287@ 2021. The Authors. Published for AMER ABRA cE-Bs by e-International Publishing House, Ltd., UK. This is an open access article under the CC BYNC-ND license (http://creativecommons.org/licenses/by-nc-nd/4.0/). Peer-review under responsibility of AMER (Association of Malaysian Environment-Behaviour Researchers), ABRA (Association of Behavioural Researchers on Asians/Africans/Arabians) and CE-Bs (Centre for Environment-Behaviour Studies), Faculty of Architecture, Planning \& Surveying, Universiti Teknologi MARA, Malaysia.

DOI: https://doi.org/10.21834/ebpj.v6i17.2867 
In Wong Hang Foh \& Ors v Tropika Istimewa Development Sdn Bhd (KL High Court Civil Suit No: WA-22NCVC-120-03/2018), the court decided that the developer has misrepresented the purchasers for selling a lease under the sale and purchase agreement (SPA) using Schedule H of the Regulations 1989. In Loh Tina \& Ors v Kemuning Setia Sdn Bhd \& Ors And Another [2020] 7CLJ 720, the developer has varied Schedule G into a PLS. The Court ordered that the lease transfer be canceled and replaced with a transfer of title favoring the purchasers. In 2019, the proposal to introduce a 'Register of Private Lease' into the National Land Code 1965 (NLC) to enable the concept of PLS was criticized and abandoned by the government. (Parliament, 2019). A PLS deprived the purchasers of property ownership, and their fate is at the mercy of the landowner to extend the lease period (Chan K.L, 2020). In brief, under a PLS, the developers only sell the building to the purchasers based on a 99-year lease without transferring the ownership of land or stratified property. Upon expiry of the 99-year old lease, the building shall be reverted to the registered proprietor. As such, the PLS shall only confer interest and not ownership of the land. The developer obtained a 99-year lease over the whole freehold land and transferred the lease to the purchasers.

As a lessee, the developer shall be bound by the NLC. Section 221 (3) of the NLC relates to the maximum term of a lease. Section 228(1) of the NLC, the lessee, shall apply for a further extension of the lease before the expiry of the said lease. The approval for further extension of the lease is at the liberty of the registered proprietor as the lessor and also subject to a new consideration to be paid by the purchasers. Section 214(1) provides that a registered lessee may transfer a lease to another third party and the implied obligation of the lessee is to obtain consent from the lessor as provided under Section 231(1)(d). Ultimately, the value of a PLS property will decrease according to the tenure of the lease. Upon expiry the purchasers lose their rights over the property. Since the current law provides transfer of ownership to the purchasers, deviating from the law by introducing a PLS Scheme shall render the sale as void. Thus, if the developers sought to use a PLS Scheme, the regulated agreement under Regulations 1989 without explaining its impact amounted to a misrepresentation that could vitiate the validity of the SPA.

This paper aims to examine the compatibility of the existing law of a lease as a private dealing under the NLC to the developers' conceptual framework of a sale of property under PLS. Simultaneously, aims to review the impact of the PLS on the purchasers who only received interest in land subject to expiration of the tenure.

\subsection{Literature Review}

\subsection{The Legal Framework of Lease under the NLC}

In Malaysia, a lease is a conveyance of land by the owner(lessor) to a lessee giving possession of the land in return for a payment. Statutorily, the word 'lease' has not been defined in the NLC. However, in Equity Corporation Sdn Bhd v Thye Sun Quarry Sdn Bhd [2002] 6 MLJ 74, even where the instrument is called an 'agreement,' it may still be construed as a valid lease. According to (Teo K.S., 2016), to constitute a lease, the lessee must be granted exclusive possession for the payment of rent. Under the NLC, a lease must be registered to create a legal interest. Registration of lease evidenced the registered interest in land (Patton, 1934). Thomson CJ, in Margaret Chua v Ho Swee Kiew \& Ors [1961] MLJ 173 held that an unregistered lease is valid as an agreement for lease. Meanwhile, in Lee Lum Soh v Low Ngah [1973] 1 MLJ 97, the Court held that an unregistered lease was "void as a lease for non-registration."

The maximum term of a lease under the NLC is 99 years if it is over the whole of the land lease. Section 221(3)(b) of the NLC only allows a maximum of 30 years over part of the land. The purchasers in PLS only purchased a unit in the high-rise building. Hence, the developer is only leasing part of the land. Thus, the purchaser's rights as a lessee in PLS will only be a maximum of 30 years. Section 228 (1) of the NLC provides that the lessor's discretion to grant the extension upon application for extension is made by the lessee. Before the expiry of the lease over the property, an application for an extension shall be made by the purchasers/lessees, and a new "price" has to be paid for the new lease tenure. Subsequently, a PLS Scheme involves a lease sale over the property where the entire "rent" is being paid upfront. Property investments are commonly known to yield capital appreciation over the long term, and indeed, the value of the leased property depreciates and incurs expenses to extend the lease (Chang KL, 2020).

\subsection{The Legal Obligations of a Developer under the HDA \& Regulations 1989}

The HDA provides guidelines for housing developers in terms of duties and responsibilities, which safeguards the rights of home purchasers (Lim G and Ng KK, 2020). There is no freedom of contract for a licensed developer, and the agreement shall use the prescribed sale agreement provided under Regulations 1989. The regulated agreement shall be complied with verbatim by the developer. Under clause 11(1), the developer is required to apply for subdivision of the property at its own cost expeditiously. Under clause 11(2), it is further required that upon the issuance of the title, transfer the property to the purchasers. In Encony Development Sdn Bhd v Robert Geoffrey Gooch \& Anor [2016] 1 CLJ 893 Nallini Pathmanathan JCA held that the provisions in the SPA are not merely contractual but are in effect statutory provisions. Any collateral contract to exist alongside the SPA violates the law that renders the contract void. In the Loh Tina, Lee Sweng Seng JCA held that a developer deviated from the HDA and Regulations 1989 by modifying the standard statutory form of SPA in Schedule $G$ without a certificate of the Controller approving the modification would be in breach of the law. The purchasers would be entitled to enforce their rights as provided under the standard Schedule $G$ of Regulations 1989. 
The PLS, as evidenced in Loh Tina, undeniably is a deviation of the regulated contract under Regulations 1989 that caused the transaction to void.

One of the schemes that were introduced was for developers to lease freehold land to the purchasers. Thus, a purchaser acquires a 99 -year lease, and the developer will negotiate for an extension of a lease. For the purchasers, an extension means payment of a total purchase price for another 99 -year lease over the same unit. The developers get a second opportunity to renew the lease or even consider redeveloping the same piece of land (Chang Kl, 2020).

\subsection{The Legal Rights of the Purchasers}

The law only recognises legal rights to a registered proprietor as opposed to a lessee, particularly regarding the protections afforded under the HDA. The dealing of "lease" does not come within the ambit of the Strata Titles Act 1985 (STA), and therefore, there is no requirement for subdivision of the building or land under the NLC or under the STA (Siang et al. 2015). Whereas, for purchasers of property, strata title is essential to the parcel owners as conclusive evidence of ownership and provides rights to become members of the management corporation and voting power. (Khadijah H. et al., 2016). The buyers are registered as the proprietor of a strata title upon issuance of the same (Commissioner of Building, Annual Report, 2015). Under Section 7 of the STA, the developers are obliged to apply for the subdivision of the building or land because it is conclusive evidence of ownership. Accordingly, a registered owner possesses the voting rights and share unit entitlements under Section 36 of the STA. However, as a lessee, a PLS purchaser is not entitled to a voting right under the Strata Management Act 2013 (SMA) because it is only vested to a proprietor of a strata title who has voting rights corresponding to the number of share units and not a lessee. Furthermore, only a registered proprietor can automatically become a Management Corporation (MC) member under the SMA (Chang KL, 2020).

The HDA protects purchasers' interest in residential property that are still under construction manifested in Veronica Lee Ha Ling \& Ors v Maxisegar Sdn Bhd. [2011] 2 MLJ 141. This case was followed in the case of Loh Tina, where the Court of Appeal held that HDA was primarily structured to shield unsuspecting purchasers against unscrupulous developers, and the deviation from the regulated contract shall be rendered as void. (Zolkafli et al. 2014) the rights of the house buyers to get ownership of the property through the regulated contract under Regulations 1989. The PLS varies from the regulated contract. The judge in Loh Tina raised a question in his judgment on "who would want a leasehold when legally they are entitled to a freehold property in a sale and purchase of a house to be built by a developer?" His Lordship also held that the HDA is designed to protect the innocent purchasers who have little or no bargaining power and are often not conscious of their legal rights under the law. Therefore, any modification to that right is ineffective, null, and void.

\subsection{Methodology}

This article is a conceptual paper that employs doctrinal research to analyse the legal position of a sale of property under a PLS Scheme both locally and in foreign jurisdictions. The study is conducted by examining primary data of legal statutes, primarily on the NLC, STA, SMA, HDA, law cases, and secondary data from various literature. The law cases and the legal reasoning given by the Court's judgement are analysed to determine the implication of PLS on the purchasers. The doctrinal method is used to seek whether PLS is a fair-andjust transaction to the purchaser regarding a property sale. The discussion in this paper is limited to looking at the laws and theoretical aspects of the concept of PLS in upholding the rights of the purchaser under the scheme. No empirical analysis is made as it focuses on a doctrinal analysis and theoretical discourse. It also seeks to review the legal implication of PLS transfer under other legislation/ jurisdictions since the concept is outside the purview of any Malaysian legislation. An analysis of a similar idea of PLS in Australia is examined through a doctrinal approach to recommend a possible legal framework of PLS to be executed in Malaysia. The data have been gathered and analysed in the findings via a content analysis approach and doctrinal study.

\subsection{Findings \& Discussions}

A leasehold scheme is a strata subdivision that enables all lots to be subjected to a fixed-term lease between 20 to 99 years. In New South Wales, the Strata Schemes Development Act 2015 regulates the leasehold scheme. Section 4 of the Strata Schemes Development Act 2015 defines a leasehold strata scheme as a strata scheme in which all lots and common property in the scheme are subject to a lease or leases. A leasehold scheme can be either a leasehold strata scheme for building or a leasehold survey-strata scheme for land with surveyed boundaries (the Government of Western Australia, 2020). With this scheme, the purchasers will own long-term leases of lots and easily sell their lease without the landlord's consent. However, this leasehold scheme is different from the freehold scheme as the ownership will be limited to the lease length, while freehold schemes have no such limitation. The minimum term of the lease will be greater than 20 years, and the maximum period will be 99 years, including any renewal option. By setting up the limitation, it can ensure certain planning obligations to be met.

Besides, each lot owner will have their certificate of title for the leasehold interest in this leasehold scheme. In Copyright Agency Ltd $v$ New South Wales (2007) 240 ALR 249, the Federal Court states that the purchaser of each lot created under the subdivision will obtain a leasehold interest rather than a freehold interest in the lot. Meanwhile, the contract of the lease will provide the leasehold interest. 
In Re Willmott Forests Ltd (2012) 91 ACSR 182, the Supreme Court of Victoria held that the contract of lease governs any leasehold interest. It is the contract that regulates the substance and termination of the leasehold interest.

Also, in Progressive Mailing House Proprietary Ltd v Tabali Proprietary Ltd (1986) 157 CLR 17, referring to Matthey v Curling [1922] 2 AC 180, the Court held that the law of contract provides for the interest of a leasehold estate. The lease of every lot will expire on the same date, and the ownership shall be returned to the leasehold scheme owner. Options to renew the lot leases can be included but with the condition that they will have a standard expiry date. The total term of renewal is subject to the maximum term of 99 years. The purpose of the standard expiry date in this leasing scheme is to ensure that the lease for every lot expires synchronously and to have proper ownership arrangements and management.

In Western Australia, any postponement of the expiry date will require approval from the Western Australia Planning Commission. The provision on termination of the scheme can be seen under Part 3 of the Strata Titles Act 1985. While in New South Wales, the termination and expiry of leases have been provided under Part 9 of the Strata Schemes Development Act 2015.

In Australia, selling a lease under a PLS means the landowner would remain the owner of all condominium units and control the condominium's management corporation. The landowner would be treated as a residential landlord and have the obligations inherent in that status. (Bucknall B, 1976). The lessor, however, will have limited rights of re-entry, and he is not responsible for the maintenance of the lot. In Western Australia, the provision on restrictions and relief against forfeiture of a lease can be seen under Section 81 of Property Law Act 1969. In New South Wales, the terms have been provided under Section 46 of Strata Schemes Development Act 2015 subjected to Section 129 of Conveyancing Act 1919. Section 81(1) of the Property Law Act 1969 and Section 129 of the Conveyancing Act 1919, the lessor shall not exercise his rights of re-entry or forfeiture. He can only re-enter after serving a notice to the lessee.

In Tim Barr Pty Ltd v Narui Gold Coast Pty Ltd [2010] NSWSC 29, the lessor can only exercise his re-entry rights if the lease contract has ended and not due to any breach of the covenant made by the lessee. Subsequently, Owen J, in Campbell $v$ Payne and Fitzgerald (1953) 53 SR (NSW) 537, held that a right to forfeit a lease might arise in the case of any breach of covenant. However, this can only be enforced if the parties agreed that a covenant violation should create forfeiture. In Re Willmott Forests Ltd (2012) 91 ACSR 182, the lessor's obligation is to provide the lessee with possession and quiet enjoyment of the land. The rights of a lessee under these covenants will be enforceable by him against the lessor either under privity of contract, or privity of estate, or both. Besides, the lessee is registered on the certificate of title as proprietor of the strata leasehold estate in the lot to secure the lessee's rights and responsibilities to pay rates and tax (Australia: Civic Legal, 2019).

In conclusion, the leasehold scheme in Australia, equivalent to the PLS, provides fixed-term leases between 20 to 99 years confers leasehold interests of a lot to the lessee with the issuance of a certificate of a lease. This leasehold scheme enables the lessee to sell, transfer, dispose of their lot, or mortgage the lease in the leasehold scheme without the lessor's consent. Undeniably, the leasehold certificate provides security of tenure to the building owner throughout the lease period and simplifies the conveyance of the property.

\subsection{Conclusion \& Recommendations}

The primary duty of the developers under the HDA is to convey a title upon issuance of the subdivided title to the purchasers. "Build and lease" under the PLS is a deviation from the protection accorded to the purchasers under the HDA, where in return for the purchase price, the purchasers will be transferred with ownership of the property. A private lease that expires at the end of a 99-year lease shall suffer a depreciation compared to an ownership of a freehold land tenure that will be valuable and could be transmitted to their beneficiaries. As the concept of PLS is new where neither HDA, NLC, nor STA contains provisions that allow the scheme, the introduction of a legal framework is essential to validate the PLS. Without the law, the PLS is not compatible with the existing legal framework on the selling of properties by developers. As such, forcing the PLS shall render the sale transaction by the developer is void. However, the PLS may be an alternative to another land ownership scheme that could offer cheaper accommodations, especially for those seeking houses within the urban areas. A certificate of a lease introduced by Australia could enhance the security of tenure and simplify the conveyance of the property. Ultimately, a PLS that issues a Lease certificate gives a broader option for anyone to have a shelter. To ensure eligibility of the Purchasers of a PLS to form the management corporation and be entitled to a legitimate voting right, the Strata Management Act 2013 should include the term lessee into the eligibility of the purchasers to form a management corporation and voting right during the Annual Meeting. An amendment of the HDA is timely by incorporating a new Schedule that could work legitimately for the unit buyers of a PLS. Alongside, the NLC and STA's revision is necessary to provide a legal platform introducing a Certificate of Lease.

\section{Acknowledgment}

This research is financially supported by Jabatan Penilaian Negara (INSPEN) Research Grant No. INSPEN.600-412/2(2). 


\section{Paper Contribution to Related Field of Study}

This paper addresses the legal implication of a PLS in light of the existing legal framework for the sale of property by developers. The suggestions provided in this research may assist the policymaker in providing a secure system of purchasing the property from developers.

\section{References}

Loong, D. C. K. (2020, December 8). Private Lease Scheme offers "no proprietary rights' for the buyers. PUON Tribune. https://puontribune.com/2020/12/08/privatelease-scheme-offers-no-proprietary-rights-for-the-buyers/

Loong, D. C. K., \& E. (2020, December 4). Beware the oppressive Private Lease Scheme. Edgeprop.My. https://www.edgeprop.my/content/1771030/bewareoppressive-private-lease-scheme

Loong, D. C.K. (2020, December 6). Private lease scheme: A risk for house buyers. Focus Malaysia. https://focusmalaysia.my/private-lease-scheme-a-risk-for-housebuyers/

Loong, D. C. K., \& E. (2020, November 6). End of Private Lease Tenure - what happens then? EdgeProp.My. https://www.edgeprop.my/content/1759245/end-privatelease-tenure-\%E2\%80\%94-what-happens-then

Department of Planning, Lands and Heritage, Government of Western Australia. (2020). Subdivision by Leasehold Scheme. https://www.dplh.wa.gov.au/policy-andlegislation/state-planning-framework/fact-sheets,-manuals-and-guidelines/subdivision-by-leasehold-scheme

Eva, Y. HBA 'no' to leasing of private land for housing. (2018, June 4). PressReader. https://www.pressreader.com/malaysia/the-sunmalaysia/20180604/281736975138799

HBA objects to leasing of private land for housing purposes. (2018, June 3). The Sun Daily. https://www.thesundaily.my/archive/hba-objects-leasing-private-landhousing-purposes-MUARCH552393

Iskandar Investment explains Medini Private Lease Scheme. (2018, July 23). The Sun Daily. https://www.thesundaily.my/archive/iskandar-investment-explains-mediniprivate-lease-scheme-DUARCH566137

Wong, J. Z. (2019). TOWARDS ENFORCEABLE STANDARDS, RULES AND RIGHTS IN STRATA MANAGEMENT: AN ANALYSIS. IIUM Law Journal, 27(2), $397-$ 446. https://doi.org/10.31436/iiumlj.v27i2.433

Hussin D. K.B., Rahman, P. S. D. M. M. G. B. M. A., \& Mohamad P. M. D. M. T. S. H. (2016). Urban Renewal and Strata Scheme Termination A Proposal for En Bloc Sale: The Malaysian Approach. NAPREC (R/D) 6/16.

Leasehold strata schemes: an introduction. (2019, December). Civic Legal. https://www.civiclegal.com.au/wp-content/uploads/2020/01/Civic-Legal-Leasehold-StrataSchemes-an-introduction.pdf

National House Buyers Association. (2018, November 21). Private Lease Scheme (PLS): A Generational Curse. Malay Mail, page 28. https://rehdaselangor.com/wpcontent/uploads/20181121_Private_Lease_Scheme_PLS_A_GenerationsI_Curse-min.pdf

Izanda, N. S. S., Samsudin S., \& Zainuddin, M. (2020). Strata Title Reforms in Malaysia: A Review and Challenges of Regulatory and Governance Panacea. European Journal and Molecular Medicine, 7(8), 413-426

Pavither, (2018, June 5). Housing Projects on Privately Leased Land Detrimental to Buyers. PropertyGuru. https://www.propertyguru.com.my/propertynews/2018/6/172418/housing-projects-on-privately-leased-land-detrimental-to-buyers

Malaysia. Parliamentary Debates, Penolakan Cadangan PLS di Parlimen (Question 1), House of Representatives, 2019, November, (Oral presentation by Ministry of Water, Land and Natural Resources)

Siang, T.E., Ying, K.C., \& Seng, J.K.Q., (2015). Gated Community- Modern Lifestyle in Urban Area: Issues and Challenges on Legal Development in Peninsular Malaysia. Malayan Law Journal, 1, Available at SSRN: https://ssrn.com/abstract=2710413

Sood, T. K. (2016). Role of equity and the application of English land law in the Malaysian Torrens System. Canterbury Law Review, 22, 40-56

Zolkafli, U., Yahya, Z., Zakaria, N., Akashah, F., Othman, M., Ali, A., \& Salleh, H. (2014). Latent Defects: Approaches in Protecting House Buyers' Right in Malaysia. MATEC Web of Conferences, 15, 01040. https://doi.org/10.1051/matecconf/20141501040 